\title{
Arts, mits bescheiden en met inzicht in eigen niet-weten. *
}

\author{
G.Th. van der Werf
}

Wat is er eenvoudiger dan onderwijs? Formuleer leerdoelen, geef uitleg, maak toetsvragen en kijk of de leerling de vereiste kennis en vaardigheid bezit; of niet. Maar een goede onderwijzer is bescheiden, die weet dat al die kennis en vaardigheid niets waard zijn, tenzij de leerling heeft geleerd open te staan voor de vragen uit de praktijk van alle dag.

Geneeskunde lijkt vaak te bestaan uit 'zeker weten' en snel, doelgericht zonder twijfel handelen, met als adagium: 'Nu ingrijpen, straks reflecteren'. Die houding past bij de technische beheersing van een instrumentele handeling, bij het heroïsche gevecht tegen ziekte en dood. Dat is een belangrijk deel van ons werk.

Een flitsende demonstratie van kennis en kunde is echter niet genoeg. Minstens even belangrijk is de samenspraak tussen arts en patiënt over de mogelijkheden en grenzen van het medisch ingrijpen. Daarbij past het adagium: 'Nu reflecteren om straks weloverwogen en doelgericht te kunnen handelen'. Stervensbegeleiding is dan de ultieme kwaliteitstoets.

Is de arts die bewezen heeft de vereiste kennis te hebben en over de nodige vaardigheid te beschikken een goede dokter? Die vraag valt slechts te beantwoorden als we een goede, valide en betrouwbaar te meten, 'harde' uitkomstmaat hebben. Ik stel drie criteria voor. Een goede dokter: (a) kent de eigen beperkingen, de beperkingen van het vak en van de geneeskunde als ge- heel; (b) is in staat openlijk uit te komen voor fouten en leert ervan; (c) is in staat beargumenteerd beslissingen te nemen in het belang van deze ene patiënt, ook als die tegen de stand van de wetenschap ingaan of indruisen tegen wat de patiënt zelf vraagt.

Kennis is van groter volmaaktheid dan twijfelen. Maar alle 'evidence' ten spijt, onze wetenschap is niet volmaakt. Wat gisteren de hoogste waarheid was, lijkt vandaag soms hopeloos verouderd. Medischwetenschappelijk onderzoek sluit zich vrijwel af voor de maatschappelijke en ethische vragen die we in de dagelijkse praktijk tegenkomen. Nascholing richt zich overwegend op overdracht van wetenschappelijke kennis. Maar in de praktijk moeten we handelen. Pas als we ons rekenschap geven van wat we niet beheersen en niet weten, is verwondering mogelijk over wat er rondom ons te zien en te doen valt. ${ }^{1}$

Toetsing met consequenties voor de beroepsuitoefening heeft alleen zin als we ook toetsen of de arts kan omgaan met de grenzen van het weten en kunnen. Bij postacademisch onderwijs past altijd: 'nu reflecteren om straks weloverwogen en doelgericht te kunnen handelen'. Daarom: beter een dokter die weinig weet en dat van zichzelf weet, dan één die ernaar streeft alles zeker te weten.

Bewaar me voor 'schriftgeleerden' die op grond van beperkte inzichten menen te kunnen beoordelen of ik voldoe aan hun normen en daar consequenties aan ver-

\footnotetext{
* Dit artikel is ook verschenen in het Nederlands Tijdschrift voor Geneeskunde (Ned Tijdschr Geneeskd. 2009;153:B305)
} 
binden. De kwaliteit van dokters schuilt niet in alwetendheid, maar in bescheidenheid, in inzicht in grenzen en beperkingen.

\section{Literatuur}

1. Zhuang Zi. De volledige geschriften. Vert. K. Schipper. Amsterdam: augustus 2007. [The complete writings. Translation K. Schipper. Amsterdam: August 2007].
De auteur:

Dr. G. (Ger) Th. van der Werf is huisarts, Huisartspraktijk, Universitair Medisch Centrum Groningen.

Correspondentieadres:

Dr. G.Th. van der Werf, huisarts, UMC Groningen; e-mail: g.th.van.der.werf@ahg.umcg.nl

Belangenconflict: geen gemeld

Financiële ondersteuning: geen gemeld 